\title{
Collagen and Proteoglycan Forms of Type IX Collagen in Chick Embryo Cartilage
}

$$
\text { ニワトリ肧軟骨のユニークな X型コラーゲンの2つの型 }
$$

\author{
Yada, T., Arai, M., Suzuki, S., and Kimata, K. J. Biol. Chem. (1992) 267, 9391-9397
}

Key Words: chick embryo, cartilage, typeIX collagen, proteoglycan, PG-Lt

The exciting story of type IX collagen actually started in 1983 when Suzuki's group isolated and characterized PG-Lt (light proteoglycan with a buoyant density of less than $1.3 \mathrm{~g} /$ $\mathrm{ml}$ ) among three proteoglycans (PGs) from chick embryo cartilage. This PG was unique in having disulfide-bonded polypeptides of collagen character. They noted markedly high contents of glycine and the degree of hydroxylation of proline and lysine, suggesting the collagen-type protein moiety. PG-Lt was also found to be digestible with collagenase(protease-free) and changed its position on gel chromatography along with the sulfated glycosaminoglycan, suggesting that the molecule is composed of collagen and PG. Furthermore, Suzuki et al. demonstrated that the core protein of PG-Lt is composed of three collagen polypeptides, subsequently named as $\alpha 1$ (IX), $\alpha 2$ (IX), and $\alpha 3$ (IX), $\alpha 2$ IX being the attachment site for glycosaminoglycan chains[Noro et al., J. Biol. Chem. (1983) 256, 93239331]. This was the landmark paper in the field of type IX collagen although the investigators did not named it as type IX collagen. Olsen and his group[Van der Rest et al., J. Biol. Chem. (1985) 260, 220-225, Nishimura et al., J. Biol. Chem. (1989) 264, 20035-20042, Ninomiya et al., Proc. Natl. Acad. Sci. USA (1984) 84, 3014-3018] presented detailed analysis both of tryptic peptides and amino-terminal sequences of the subunits of two collagenous fragments(HMW and LMW) of a unique collagen composed of molecules with three different polypeptide chains ( $\alpha$ chains). Olsen named this molecule as Type IX collagen. Furthermore, Olsen and his group constructed a cDNA library for embryonic chicken sternal cartilage. mRNA was isolated and characterized. 3,200 bp cDNA codes for collagenous polypeptide. The supportive data for this unique collagen came from the laboratory of Vaughan[Vaughan et al., J. Biol. Chem. (1985) 260, 4758-4763, Bruner et al., Proc. Natl. Acad. Sci. USA (1985) 82, 2608-2612] when they isolated and characterized the molecule from sternal cartilage of chicken embryos. Type IX collagen is the resident of many other tissues besides cartilage. Suzuki and his group demonstrated the presence of type IX collagen with a very large chondroitin sulfate chain $(350 \mathrm{k})$ in chick embryo vitreous humor. This collagen IX had a high buoyant density than type IX collagen of the cartilage.

In the present report, Yada et al. have isolated a type IX collagen metabolically labeled with ${ }^{3} \mathrm{H}$-proline using an anti-
珍しい構造をしたX型コラーゲンの発見は、実際には当時 名古屋大学の鈴木旺の研究室でニワトリ胚軟骨から、PG-Lt(浮 力密度 $1.3 \mathrm{~g} / \mathrm{ml}$ 以下の軽いプロテオグリカンという意味で名付け られた)を見出してその性質を記載した時にさかのほる。この PGはジスルフィド結合で結びつけられたコラーゲン様のポリベ プチドを持っているという点でユニークであった。グリシン含 量が高く、プロリンとリジンの水酸化の程度が高いのでコラー ゲン様のタンパク質と考えられた。このPG-Ltはタンパク質分 解酵素を含まないコラゲナーゼで分解されてゲルクロマトグラ フィー上で溶出位置を変えるが、硫酸化グリコサミノグリカン の位置も一緒に移動するので、この分子はコラーゲンとプロテ オグリカン両者を含む分子と思われた。さらに鈴木らはPG-Lt のコアタンパク質は3本のコラーゲンポリペプチド鎖(のちに $\alpha 1(\mathrm{IX}) 、 \alpha 2(\mathrm{IX}) 、 \alpha 3(\mathrm{IX})$ と名付けられた)から成り、 $\alpha 2$ にグリコ サミノグリカン鎖が付いていることを示した[Noro et al., J. Biol. Chem. (1983) 256, 9323-9331]。鈴木らはこの時はIX型コラーゲ ンとは命名しなかったが、これがIX型コラーゲン研究では画期 的な論文となった。Olsenらは異なる3本の $\alpha$ 鎖から成るコラー ゲンのうちの 2 本(HMWとLMW)のトリプシン分解ペプチドとN 末端アミノ酸配列について詳細な研究を行なった[Van der Rest et al, J. Biol. Chem. (1985) 260, 220-225, Nishimura et al., J. Biol. Chem. (1989) 264, 20035-20042, Ninomiya et al., Proc. Natl. Acad. Sci. USA (1984) 81, 3014-3018]。Olsonはこの分子をIX型コラー ゲンと命名し、ニワトリ肧胸軟骨からcDNAライブラリーを作 成した。mRNAがとられたが、cDNAはコラーゲン様ポリペプ チドをコードする3,200bpの長さであった。Vaughanの研究室も [Vaughan et al. , J. Biol. Chem. (1985) 260, 4758-4763, Bruner et al., Proc. Natl. Acad. Sci. USA. (1985) 82, 2608-2612]ニワトリ肧胸軟 骨からこのユニークなコラーゲンを抽出し同定している。この IX 型コラーゲンは軟骨以外の様々な組織からも見出されてい る。鈴木研究室はニワトリ胚眼のガラス様液から異常に長い (350kDa)コンドロイチン硫酸鎖1本を持つIX型コラーゲンを見出 している。このコラーゲンは軟骨のIX型コラーゲンに較べて浮 力密度が高い。

さてここに紹介する論文で、矢田らはIX型コラーゲンに対 
body to type IX collagen. They found that the molecule is synthesized in two forms, a collagen form(COLIX) and proteoglycan form(PGIX). The labeled tissue was extracted with $1 \mathrm{M}$ sodium chloride. The extract was subjected to affinity chromatography using an antibody towards type IX coupled with Sepharose 4B gel column. Bound molecules were eluted with 3 M KSCN and analyzed by SDS-PAGE. A diffused double band consisting of a low mobility and a sharp band of higher mobility were observed with relative molecular sizes of 300 $\mathrm{kDa}$ and $270 \mathrm{kDa}$. Both bands were digestible with collagenase (protease-free). The bound molecules were fractionated on DEAE-Sephacel chromatography. The unbound fraction gave a single band of at $270 \mathrm{kDa}$ on SDS-PAGE regardless of Chondroitinase $\mathrm{ABC}$ digestion. The bound fraction was eluted with $0.45 \mathrm{M}$ sodium chloride. On SDS-PAGE the bound fraction showed a diffuse band of $300 \mathrm{kDa}$. Upon Chondroitinase $\mathrm{ABC}$ digestion a single band of $270 \mathrm{kDa}$ was observed. Under reduced condition(SDS-PAGE) both fractions yielded two bands of Mr 84,000 and 68,000(a doublet). Thus, it was clearly shown that the type IX collagen consisted of a $270 \mathrm{kDa}$ collagen form(COLIX) and a $300 \mathrm{kDa}$ proteoglycan form(PGIX). The proportions of these molecules were $22 \%$ and $78 \%$ respectively. In order to confirm two independent forms of type IX collagen investigators carried out a pulse-chase experiment with cultured chondrocytes from the tissue. $1 \mathrm{M}$ sodium chloride extracts were prepared from the cell layer and the medium and each extract was subjected to immunoprecipitation with anti-type IX collagen antibody. During the pulse period, the cell layer fraction showed the presence of three components; $300 \mathrm{kDa}, 270 \mathrm{kDa}$, and $265 \mathrm{kDa}$. The medium fraction contained only one component, $300 \mathrm{kDa}$ Mr. After $10 \mathrm{hr}$ of chase with cold type IX collagen, $265 \mathrm{kDa}$ component was completely lost, suggesting that $265 \mathrm{kDa}$ was a precursor of 270 $\mathrm{kDa}$ and $300 \mathrm{kDa}$ components. The incorporation of ${ }^{35} \mathrm{~S}$ sulfate into above components showed that only $300 \mathrm{kDa}$ component was labeled indicating that it is PGIX.

It has been shown previously that $\mathrm{NC} 3$ domain of the $\alpha 2$-IX chain was 5 amino acids residues longer than that of a1IX chain and the serine residue in this sequence may serve as the GAG attachment site. This external-loop-like structure (kink) may be antigenic and its antigenicity may be altered after the GAG attachment. If this is so, investigators reasoned that if an antibody can be raised against a synthetic peptide of the known sequence including 5 amino acid residues it can be used as a probe to distinguish between COLIX and PGIX portions of the polypeptide. Accordingly, they synthesized an undecapeptide having a partial sequence of NC3 domain and coupled it to hemocyanin through its carboxyl terminal cysteinyl residue. This hapten-carrier complex was injected into rabbits to raise antibodies. Such antibodies were found to recognize the synthetic peptide and COLIX on an ELISA. These reactions were

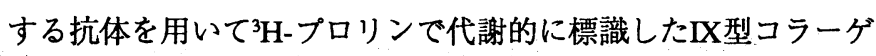
ンを単離し、この分子はコラーゲン型(COLIX)とプロテオグリ カン型(PGIX)の2種の型として合成されることを見出した。標 識した組織を1M塩化ナトリウムで抽出し、抗IX型コラーゲン抗 体をセファロース4Bゲルカラムにつけたアフィニティクロマト

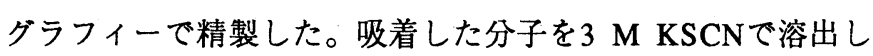
SDS-PAGEで分析すると、300 kDaの遅い移動度のほやけたバン ドと $270 \mathrm{kDa}$ の速い移動度のシャープなバンドから成っていた。 どちらのバンドもプロテアーゼを含まないコラゲナーゼで分解 できた。これらのバンドをDEAE-セファセルクロマトグラ フィーで分画すると、吸着しない画分はコンドロイチナーゼ $\mathrm{ABC}$ 消化の有無にかかわらずSDS-PAGEで $270 \mathrm{kDa}$ の単一バンド を与えた。DEAEに吸着する画分は $0.45 \mathrm{M}$ 塩化ナトリウムで溶 出され、SDS-PAGEでは $300 \mathrm{kDa}$ 拡がったバンドを与えた。こ れをコンドロイチナーゼABCで消化すると $270 \mathrm{kDa}$ の単一バンド が得られた。還元条件のSDS-PAGEでは両分画とも分子量 84,000 と64,000(ダブレット)の2本のバンドを生じた。したがっ て、IX型コラーゲンは270 kDaのコラーゲン型(COLIX)と300 $\mathrm{kDa}$ のプロテオグリカン型(PGIX)から成ることが明らかとなっ

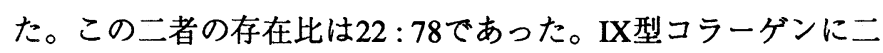
つの独立の型が存在することを確実に証明するために、彼等は 組織から、単離した軟骨細胞を培養し、パルスーチェイス実験 を行なった。細胞と培養上清それぞれから $1 \mathrm{M}$ 塩化ナトリウム で抽出した液を抗X型コラーゲン抗体で免疫沈降させた。パル ス標識している時細胞には $300 \mathrm{kDa} 、 270 \mathrm{kDa} 、 265 \mathrm{kDa}$ の成分 があった。上清には $300 \mathrm{kDa}$ のであった。10時間チェイスする と $265 \mathrm{kDa}$ 成分は完全に消失したので、265 kDaは $270 \mathrm{kDa}$ と 300 $\mathrm{kDa}$ 成分の前駆体であると思われた。 ${ }^{35} \mathrm{~S}$-硫酸のとりこみは300 $\mathrm{kDa}$ 成分にのみ見られたので、 $300 \mathrm{kDa}$ 成分がPGIXということに なる。

$\alpha 2-\mathrm{IX}$ 鎖のNC3ドメインは $\alpha 1-\mathrm{IX}$ 鎖のそれよりも長く5個の アミノ酸残基からなり、この配列の中のセリン残基にGAG鎖が 付着していることが以前に示されている。この外部に向けて ループ状に突き出した構造(kink)に抗原性があり、その抗原性は GAGの付着により変化すると思われる。とするなら、この5ア ミノ酸残基を含む合成ペプチドに対して抗体を作らせれば、ポ リペプチドのCOLIXとPGIX部分を区別できるのではないかと彼 等は考えた。彼等はNC3ドメインの部分配列を含む11アミノ酸 残基からなるペプチドを合成し、C末のシステイン残基を介し てへモシアニンにくっつけた。このパプテンを含む複合体をウ サギに注射して免疫し、得られた抗体はELISAアッセイで合成 ペプチドとCOLIXを認識した。この反応は、合成ペプチドを加 えることで拮抗的に阻害できた。一方、抗体はPGIXと反応しな 
competitively inhibited by the addition of a free synthetic peptide. Antibodies failed to recognize PGIX. However, a more rigorous proof was necessary to show that the negative reactivity is due to the presence of a GAG chain and the basic core structure is still immunopositive. The conventional method of removing the GAG chain by treatment of PGIX with alkali or bxylosidase is not suitable as in the alkali treatment the serine residue is converted into dehydroalanine and xylosidase is only active with the linkage region of a short peptide. Therefore, investigators approached the problem in a different fashion. Collagenase-resistant short peptides containing the GAG chain (GAG-NC3 peptides) were prepared from PGIX and were treated with endo $\beta$-xylosidase. As expected, the treatment resulted in the positive reactivity with anti-NC3 peptide antibodies. These results suggested that anti-NC3 peptide antibodies recognize COLIX without any modification of the serine residue in the NC3 domain.

For the first time, two independent forms of type IX collagen have been demonstrated. The physiological significance of these forms are not known at present. However, these components are expected to play an important role(s) in the cartilage matrix assembly. COLIX, PGIX and the aggregating PG(Aggrecan) together may be functioning in this process. It has been speculated that type IX collagen may play an important role in the stabilization of the fine network of collagenous fibers by preventing the formation of large fibers of type II collagen. Anti-NC3 antibody may be a useful tool to decipher the mechanism of matrix assembly at the tissue level.

\section{Reported by Shridhar P. Damle}

The Rockefeller University,

New York, U.S.A.
かったが、それはGAG鎖の存在のために阻害されているのかも 知れず、基本的なコア構造は免疫反応を陽性であることを明確 に示さなくてはならなかった。GAG鎖を除くためにPGIXをア ルカリで処理したり、 $\beta$-キシロシダーゼで処理することは適切 ではない。アルカリ処理( $\beta$-脱離反応)ではセリン残基はデヒド ロアラニンに変換してしまうし、キシロシダーゼは短いペプチ ドに付いた場合にしか働らかないからである。したがって、彼 等は別のアプローチを行なった。PGIXからGAG鎖を含みコラ ゲナーゼでもはや分解を受けない短いペプチド(GAG-NC3ペプ チド)を調製してエンド- $\beta$-キシロシダーゼで処理する と、期待したように、抗NC3抗体と反応するようになったので ある。このことはNC3ドメインのセリン残基に何も修飾のない 時に抗NC3抗体はCOLIXを認識することを意味していよう。

この研究で、IX型コラーゲンに独立の2つの型のあること

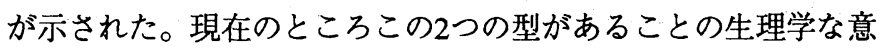
味は不明である。しかし、これらの成分は軟骨マトリックスの 構築に重要な役割を果していることが期待できる。COLIX、 PGIX、およびアグリカン(凝集型のPG)すべてがこの構築に役 立っているだろう。IX型コラーゲンの大きな瀻維形成を妨げる ことでコラーゲン繊維による微細ネットワークを安定化するの にこのIX型コラーゲンは役立っているかも知れない。抗NC3抗 体は組織レベルでのマトリックス構築のメカニズムを解明する のに有効な道具となるものと思われる。

$$
\begin{aligned}
& \text { シュリダール P. ダムレ } \\
& \text { ロックフェラー大学 }
\end{aligned}
$$

\section{三菱化成生命科学研究所・複合糖質研究室}

山形 達也訳 